\title{
Effect of high-pressure processing on reduction of Listeria monocytogenes in packaged Queso Fresco ${ }^{1}$
}

\author{
P. M. Tomasula, ${ }^{2}{ }^{2}$ J. A. Renye, ${ }^{\star}$ D. L. Van Hekken, ${ }^{*}$ M. H. Tunick, ${ }^{\star}$ R. Kwoczak, ${ }^{*}$ M. Toht, ${ }^{*}$ L. N. Leggett, $\dagger$ \\ J. B. Luchansky, $¥$ A. C. S. Porto-Fett, $¥$ and J. G. Phillips§ \\ *Dairy and Functional Foods Research Unit, United States Department of Agriculture, Agricultural Research Service, \\ Eastern Regional Research Center, 600 E. Mermaid Lane, Wyndmoor, PA 19038 \\ †Smithfield Foods Inc., Smithfield, VA 23430 \\ $\ddagger$ Food Safety and Intervention Technologies Research Unit, and \\ §Office of the Area Director, United States Department of Agriculture, Agricultural Research Service, Eastern Regional Research Center, \\ 600 E. Mermaid Lane, Wyndmoor, PA 19038
}

\section{ABSTRACT}

The effect of high-hydrostatic-pressure processing (HPP) on the survival of a 5-strain rifampicin-resistant cocktail of Listeria monocytogenes in Queso Fresco (QF) was evaluated as a postpackaging intervention. Queso Fresco was made using pasteurized, homogenized milk, and was starter-free and not pressed. In phase $1, \mathrm{QF}$ slices $(12.7 \times 7.6 \times 1 \mathrm{~cm})$, weighing from 52 to $66 \mathrm{~g}$, were surface inoculated with $L$. monocytogenes (ca. 5.0 $\log _{10} \mathrm{cfu} / \mathrm{g}$ ) and individually double vacuum packaged. The slices were then warmed to either 20 or $40^{\circ} \mathrm{C}$ and HPP treated at 200, 400, and $600 \mathrm{MPa}$ for hold times of $5,10,15$, or $20 \mathrm{~min}$. Treatment at $600 \mathrm{MPa}$ was most effective in reducing $L$. monocytogenes to below the detection level of $0.91 \log _{10} \mathrm{cfu} / \mathrm{g}$ at all hold times and temperatures. High-hydrostatic-pressure processing at $40^{\circ} \mathrm{C}, 400 \mathrm{MPa}$, and hold time $\geq 15$ min was effective but resulted in wheying-off and textural changes. In phase 2, L. monocytogenes was inoculated either on the slices (ca. $5.0 \log _{10} \mathrm{cfu} / \mathrm{g} ; \mathrm{ON}$ ) or in the curds (ca. 7.0 $\log _{10} \mathrm{cfu} / \mathrm{g}$; IN) before the cheese block was formed and sliced. The slices were treated at $20^{\circ} \mathrm{C}$ and $600 \mathrm{MPa}$ at hold times of 3, 10, and $20 \mathrm{~min}$, and then stored at 4 and $10^{\circ} \mathrm{C}$ for $60 \mathrm{~d}$. For both treatments, L. monocytogenes became less resistant to pressure as hold time increased, with greater percentages of injured cells at 3 and 10 min than at $20 \mathrm{~min}$, at which the lethality of the process increased. For the IN treatment, with hold times of 3 and $10 \mathrm{~min}$, growth of L. monocytogenes increased the first week of storage, but was delayed for $1 \mathrm{wk}$, with a hold time of $20 \mathrm{~min}$. Longer lag times in growth of $L$. monocytogenes during storage at $4^{\circ} \mathrm{C}$ were

\footnotetext{
Received September 29, 2013.

Accepted November 28, 2013.

${ }^{1}$ Mention of trade names or commercial products in this publication is solely for the purpose of providing specific information and does not imply recommendation or endorsement by the USDA.

${ }^{2}$ Corresponding author: peggy.tomasula@ars.usda.gov
}

observed for the ON treatment at hold times of 10 and 20 min, indicating that the IN treatment may have provided a more protective environment with less injury to the cells than the ON treatment. Similarly, HPP treatment for 10 min followed by storage at $4^{\circ} \mathrm{C}$ was the best method for suppressing the growth of the endogenous microflora with bacterial counts remaining below the level of detection for 2 out of the $3 \mathrm{QF}$ samples for up to $84 \mathrm{~d}$. Lag times in growth were not observed during storage of $\mathrm{QF}$ at $10^{\circ} \mathrm{C}$. Although $\mathrm{HPP}$ reduced $L$. monocytogenes immediately after processing, a second preservation technique is necessary to control growth of L. monocytogenes during cold storage. However, the results also showed that HPP would be effective for slowing the growth of microorganisms that can shorten the shelf life of QF.

Key words: high-pressure processing, Queso Fresco, Listeria monocytogenes, microbial inactivation

\section{INTRODUCTION}

In the United States, fresh cheeses are manufactured from pasteurized milk to eliminate pathogens, if present, and to lower the levels of microflora that can reduce shelf life and affect the textural and sensory properties of the cheese. One of the most popular of the fresh cheeses is Queso Fresco (QF), which is a Hispanicstyle cheese distinguished by its bright white texture, crumbliness, mild salty flavor and non-melting characteristics. However, its high $\mathrm{pH}$ and moisture content provide the ideal conditions for growth of bacteria and other microflora, which can limit its shelf life (Leggett et al., 2012). Despite the use of pasteurized milk, QF and other fresh cheeses made commercially have been subject to occasional recalls, most likely due to environmental contamination by Listeria monocytogenes (Lin et al., 2006; Soni et al., 2010).

Postpasteurization L. monocytogenes contamination likely occurs both at the surface and the interior of 
the cheese due to processing steps that may involve handling of the curd and use of utensils (Sandra et al., 2004; Soni et al., 2010; Leggett et al., 2012) or during the milling step in manufacture, which is used to impart a crumbly texture to the curd (Van Hekken et al., 2012). Although larger, modern QF plants conduct manufacturing in closed vats so that the cheese has little contact with the environment, the hoops used for pressing and shaping the cheese may be packed by hand.

In a study to assess the viability of $L$. monocytogenes when introduced as an environmental pathogen, Leggett et al. (2012) demonstrated that QF inoculated with $L$. monocytogenes showed a maximum population density of $7.80 \log _{10} \mathrm{cfu} / \mathrm{g}$ of cheese after $20 \mathrm{~d}$ of storage at either 4 or $10^{\circ} \mathrm{C}$. The levels of indigenous bacteria and other microflora, such as yeasts and molds, also increased significantly by $28 \mathrm{~d}$ of storage. The use of postlethality interventions such as high-hydrostaticpressure processing (HPP; Hnosko et al., 2012; Leggett et al., 2012) on packaged cheese or the inclusion of antimicrobials (Soni et al., 2010, 2012) in the packaging of the cheese have been suggested to control the growth of L. monocytogenes during cold storage and additionally slow or prevent the growth of indigenous bacteria, thus extending shelf life.

The application of pressure to a sample through a pressurized fluid via HPP is an effective method for inactivation of pathogens, such as L. monocytogenes and spoilage organisms under room temperature conditions, and spores at elevated temperatures, in a variety of food products such as guacamole, salsa, fruit juices, meats, and seafood (Rastogi et al., 2007; Zhang and Mittal, 2008; Simonin et al., 2012). High-hydrostaticpressure processing is growing as a processing method or intervention technology of choice because of its demonstrated ability to economically extend shelf life and preserve the quality of food, as heat is not applied. Unlike interventions, such as antimicrobials or oils, which are usually applied to the surface of a food product, HPP operates according to the isostatic principle, in which the pressure applied to a sample through a pressurized medium such as water or oil is instantaneous and uniform throughout the sample, regardless of its volume or shape, thus inactivating microbes throughout a sample (Rastogi et al., 2007).

Although HPP is typically conducted under room temperature conditions, the temperature of the solid or liquid sample and the pressurizing fluid will increase when pressure is applied, assuming no loss of heat from the walls of the pressure chamber. This is due to the work of adiabatic compression, which interrupts the intermolecular forces of the pressuring fluid and the sample, causing a temperature increase in both (Denys et al., 2000; Ardia et al., 2004; Knoerzer and Versteeg, 2009). The compression heating factor $(\Delta T / \Delta P)$ is given by

$$
\Delta T / \Delta P=\beta T / \rho C_{p}
$$

where $T$ is the temperature (absolute $\mathrm{K}$ ), $P$ is the pressure $(\mathrm{Pa}), \beta$ is the coefficient of thermal expansion $\left(\mathrm{K}^{-1}\right), \rho$ is the density $\left(\mathrm{kg} / \mathrm{m}^{3}\right)$, and $C_{p}$ is the heat capacity $(\mathrm{J} / \mathrm{kg} \cdot \mathrm{K})$.

In accordance with Le Chatelier's principle, interruption of intermolecular forces by pressurization leads not only to an increase in sample temperature, which in the case of cheese, depends on composition (Hnosko et al., 2012; Van Hekken et al., 2013), but a decrease in the volume of water, which is a response by the sample to restore the various equilibria that were in operation before HPP (Huppertz et al., 2006). For cheese, adjustments in the intermolecular forces are reflected in changes in the microbiological, physicochemical, rheological, and sensory properties upon HPP treatment and after (Martínez-Rodríguez et al., 2012). Highhydrostatic-pressure processing treatment of cheese has been shown to lead to a reorganization of water molecules around the ions, changes in the amount of free and unbound water molecules (Martínez-Rodríguez et al., 2012), and more compact structures, which affect the mineral balance of cheese, enzyme interactions, and protein conformation (Knorr et al., 2006). The covalent bonds remain intact after HPP but the secondary structures are denatured and changes in the tertiary structures, maintained by the hydrophobic and ionic interactions, occur at applied pressures > $200 \mathrm{MPa}$ (Hendrickx et al., 1998; Chawla et al., 2011).

High-hydrostatic-pressure processing applied to QF does not significantly change its traditional properties. For QF in particular, which is known for its color and crumbliness, HPP conducted at $400 \mathrm{MPa}$ resulted in QF that was more yellow compared with the control (Sandra et al., 2004). However, Van Hekken et al. (2013) found that QF made without starter culture and not pressed, treated by HPP at 200 or $400 \mathrm{MPa}$ at an initial cheese temperature of $20^{\circ} \mathrm{C}$, had the same color as untreated samples. Only QF treated at an initial temperature of $40^{\circ} \mathrm{C}$ by $\mathrm{HPP}$ at 200,400 , or $600 \mathrm{MPa}$ was slightly more yellow than the control. Crumbliness of QF was not adversely affected with treatment at 400 $\mathrm{MPa}$, a 20-min hold time, and $20^{\circ} \mathrm{C}$ compared with the control (Sandra et al., 2004). Van Hekken et al. (2013) also found that HPP at 200, 400, and $600 \mathrm{MPa}$ and initial $\mathrm{QF}$ temperature of $20^{\circ} \mathrm{C}$ with up to a 20 -min hold time resulted in a texture similar to the control. However, for QF manufactured with a starter culture and $\mathrm{pH}$ 5.0, HPP applied at 400 and $600 \mathrm{MPa}$ for 1 
to 25 min did not maintain the signature crumbliness (Hnosko et al., 2012).

High-hydrostatic-pressure processing has already been shown to be an effective option for reduction or inactivation of $L$. monocytogenes and spoilage microorganisms from cheese (Martínez-Rodríguez et al., 2012), but few studies have been conducted to examine the effectiveness of HPP for elimination of L. monocytogenes and other microflora on high-moisture cheeses such as QF. The extent of microbial inactivation using HPP is affected by applied pressure, initial substrate temperature, hold time, food substrate and composition, the presence of antimicrobial compounds, and the pressure resistance of the microorganisms (Smelt, 1998; Chen and Hoover, 2003; Patterson, 2005; Hayman et al., 2007). Although inactivation of microorganisms by HPP has been attributed to cell death because of loss of cytoplasmic membrane integrity, partial loss of membrane integrity does not necessarily lead to cell death but demonstrates sublethal injury to the cells (Ritz et al., 2001; López-Pedemonte et al., 2007) and accounts for the growth of cells after treatment. Hnosko et al. (2012) showed greater than 5-log reductions of Listeria innocua for HPP treatment pressures of 500, 550, and $600 \mathrm{MPa}$ at hold times of 15,3 , and $1 \mathrm{~min}$, respectively, but the inactivation was described as not permanent.

Thus, the objective of this study was to examine the effects of HPP temperature, pressure, and hold time on inactivation of L. monocytogenes inoculated both in and on packaged slices of QF and to follow growth of $L$. monocytogenes throughout refrigerated storage at 4 and $10^{\circ} \mathrm{C}$. Total molds and yeasts and total aerobic mesophilic bacteria were also monitored throughout storage for select samples.

\section{MATERIALS AND METHODS}

\section{QF Manufacture}

One hundred and eighty kilograms of raw cow milk obtained from a local farm was stored overnight at $4^{\circ} \mathrm{C}$ and then standardized to $3.5 \%$ (wt/wt) fat content. The milk was then homogenized and pasteurized at $72^{\circ} \mathrm{C}$ for $15 \mathrm{~s}$ (Universal Pilot Plant; Waukesha CherryBurrell, Philadelphia, PA). Queso Fresco was manufactured in 5 separate trials according to the commercial procedure as previously described (Leggett et al., 2012; Van Hekken et al., 2013) in which starter cultures were not used and salt was added at $14.5 \mathrm{~g}$ of $\mathrm{NaCl} / \mathrm{L}$ of milk. The salt was divided into 3 portions and added in 3 applications with 10 min of stirring between each to ensure that it was evenly distributed throughout the cheese. The cheese was not pressed. Curd yield ranged from 29 to $31 \mathrm{~kg}$.
The curds were cut into approximately 5 - to $10-\mathrm{cm}-$ thick pieces, cooled to an internal temperature of $21^{\circ} \mathrm{C}$, milled, and then packed into molds for overnight storage at $4^{\circ} \mathrm{C}$ (Leggett et al., 2012). The cheese was sliced into about $12.5 \times 7.6 \times 1.0-\mathrm{cm}$ rectangular prisms, each weighing from 52 to $66 \mathrm{~g}$.

\section{High-Pressure Operations}

High-hydrostatic-pressure processing experiments were conducted using an Avure model 2L-700 highpressure food processor (Avure Technologies Inc., Columbus, $\mathrm{OH}$ ). The pressure limit of the system is 690 $\mathrm{MPa}$ and the temperature operating range is from 10 to $90^{\circ} \mathrm{C}$. The construction of the unit was described in Van Hekken et al. (2013). The basket for holding the cheese samples has dimensions of $24.1 \mathrm{~cm}$ high $\times$ $7.6 \mathrm{~cm}$ i.d. Two thermowells for type $\mathrm{K}$ thermocouples extend into the basket, with one extending approximately $5.1 \mathrm{~cm}$ to the top of the basket (measured as the length of the thermocouple extending from the upper closure of the HPP unit) and the other extending about $12.7 \mathrm{~cm}$ into the basket when the upper closure is in position. The pressure medium was filtered distilled water and was pumped through the lower closure during operation. A control system regulated heating of the pressure medium to the set-point temperature, pressurizing the vessel to the set-point pressure, setting the holding time, and controlling the vessel depressurization back to atmospheric pressure. The times to reach the pressures of 200,400 or $600 \mathrm{MPa}$ used in the experiments were $1.3,1.9$, and $2.5 \mathrm{~min}$, respectively, with depressurization time of $0.5 \mathrm{~s}$. The HPP unit was regulated by a control system that contains a recipe editor to define the set points of the system operation. System operation included steps for heating of the pressurizing fluid to the set-point temperature, pressurizing the vessel to the set-point pressure, setting the holding time for the chosen temperature and pressure, and vessel depressurization to atmospheric pressure. The real-time responses of pressure versus holding time and temperature versus holding time were displayed on a computer monitor.

\section{Inoculation Procedures with Listeria monocytogenes Strains}

As described previously (Leggett et al., 2012), approximately equal numbers of 5 rifampicin-resistant (Rif $; 100$ g/mL; Sigma Chemical Co., St. Louis, MO) strains of L. monocytogenes (MFS 53, MFS 1365, MFS 104, MFS 1363, and MFS 1394) were used in this study to inoculate both the cheese curds before molding and slicing (IN treatment) or the surface of cheese slices (ON treatment). 
Preliminary experiments showed high levels of indigenous microflora in QF during an extended shelf life. To recover only the inoculated $L$. monocytogenes, the indigenous microorganisms were suppressed by using selective agar supplemented with the antibiotic rifampicin. The 5 -strain, rifampicin-resistant $(10 \mathrm{mg} / \mathrm{mL})$ L. monocytogenes was obtained by streaking a portion $(\leq 100 \mu \mathrm{L})$ of a semi-frozen suspension of each strain separately onto brain-heart infusion (BHI) agar and incubating overnight at $37^{\circ} \mathrm{C}$. A single colony of each strain was then transferred individually into $10 \mathrm{~mL}$ of BHI broth and incubated at $37^{\circ} \mathrm{C}$ with shaking (100 $\mathrm{rpm}$ ) for $24 \mathrm{~h}$. One hundred microliters was transferred into $10 \mathrm{~mL}$ of fresh $\mathrm{BHI}$ broth and incubated at $37^{\circ} \mathrm{C}$ for $18 \mathrm{~h}$ with shaking to attain a population of stationaryphase cells. To generate the rifampicin-resistant populations, $100-\mu \mathrm{L}$ portions of each strain were spread-plated onto BHI agar containing $50 \mu \mathrm{g}$ of rifampicin $/ \mathrm{mL}$ and incubated at $37^{\circ} \mathrm{C}$ until colonies appeared on the plate. Then, a single colony was transferred and spread for isolation onto BHI agar containing $100 \mu \mathrm{g} / \mathrm{mL}$ levels of rifampicin using an inoculating loop. To prepare the cocktail, approximately equal volumes of cell suspensions of each rifampicin-resistant $(10 \mathrm{mg} / \mathrm{mL})$ strain of L. monocytogenes were combined, and the final volume was adjusted to $200 \mathrm{~mL}$ with sterile $0.1 \%$ peptone water to yield ca. $5 \log _{10} \mathrm{cfu} / \mathrm{mL}$.

\section{Preliminary HPP Trials}

In phase I of this study, preliminary experiments were conducted to identify the optimal temperature and pressure combinations for reducing the numbers of L. monocytogenes inoculated on the cheese by HPP. Using the procedures described in Leggett et al. (2012), approximately $6 \mathrm{~kg}$ of the milled curds from each of 2 cheesemaking trials was removed from hoops, stored overnight at $4^{\circ} \mathrm{C}$, and then cut into approximately 12.5 $\times 7.5 \times 1.0$-cm slices (ca. 52 to $66 \mathrm{~g}$ ), with each slice weighing from about 52 to $66 \mathrm{~g}$. Slices were individually surface inoculated with $50 \mu \mathrm{L}$ per face of the multistrain L. monocytogenes cocktail to a target level of ca. 5.0 $\log _{10} \mathrm{cfu} / \mathrm{g}$. Uninoculated samples served as controls.

After inoculation, individual slices of the cheeses were vacuum packaged (Ultravac; Koch Equipment LLC, Kansas City, MO) into sterile $10.1 \times 20.3-\mathrm{cm}$ 3-mil nylon-polyethylene bags (Prime Source Vacuum Products, San Jose, CA) and stored at $4^{\circ} \mathrm{C}$ until HPP treatment on the same day. Prior to each HPP treatment, 3 of the individually packaged cheese slices were placed into a second sterile nylon-polyethylene bag and then vacuum packaged.

The preliminary HPP trials were conducted with QF at 2 initial temperatures $\left(20\right.$ and $\left.40^{\circ} \mathrm{C}\right), 3$ pressures
(200, 400, and $600 \mathrm{MPa})$, and 4 holding times (5, 10 , 15 , and $20 \mathrm{~min}$ ). Prior to being treated, the sample bag containing 3 individually vacuum-packaged QF slices was folded over twice and placed between the thermowells on the underside of the upper closure of the HPP apparatus. While holding the sample, the basket was screwed to the underside of the upper closure and then lowered into the pressure vessel. For experiments conducted at $20^{\circ} \mathrm{C}$, the samples that were stored at $4^{\circ} \mathrm{C}$ were warmed in a water bath to $20^{\circ} \mathrm{C}$ before HPP. For experiments conducted at $40^{\circ} \mathrm{C}$, the sample bag containing the 3 individually vacuum-packaged QF slices was warmed in a water bath for about 2 min until the center of the cheese reached approximately $40^{\circ} \mathrm{C}$. The temperature of the pressurizing water was set to $40^{\circ} \mathrm{C}$. After processing, the samples were stored at $4^{\circ} \mathrm{C}$ until assayed the following day.

\section{Storage of HPP-Treated QF}

The preliminary trials demonstrated that $\mathrm{QF}$ at an initial temperature of $20^{\circ} \mathrm{C}$ and treatment pressure of $600 \mathrm{MPa}$ would decrease $L$. monocytogenes below detection levels if on the surface of QF. In phase II of this study, in each of 3 cheesemaking trials, $8 \mathrm{~kg}$ of the $\mathrm{QF}$ milled curds were inoculated to a final concentration of about 5 to $7.0 \log _{10} \mathrm{cfu} / \mathrm{g}$, mixed to distribute the inoculum throughout the curd, hand-packed into molds, and then stored overnight at $4^{\circ} \mathrm{C}$ as previously described (Leggett et al., 2012). On the following day, the cheese was removed from the molds and sliced as described above for the first phase of this study. These slices are referred to as the IN treatment slices. The remaining $8 \mathrm{~kg}$ of milled curds was prepared as described above in phase I for the ON treatment. Both the IN and ON slices were vacuum packaged as described above. Next, the IN and $\mathrm{ON}$ slices with an initial temperature of $20^{\circ} \mathrm{C}$ were treated at $600 \mathrm{MPa}$ for holding times of 3 , 10, and $20 \mathrm{~min}$. After treatment, the slices were stored at 4 or $10^{\circ} \mathrm{C}$ and sampled on $\mathrm{d} 0,7,14,28,42$, and 60 .

\section{Enumeration of L. monocytogenes}

The sampling and enumeration procedures for $\mathrm{QF}$ inoculated with L. monocytogenes have been described previously (Leggett et al., 2012). Briefly, each slice was weighed after opening the ethanol-sterilized packages, combined in a filter bag (model XX-C003; Microbiology International, Frederick, MD) with $75 \mathrm{~mL}$ of sterile $0.1 \%$ peptone water (Becton, Dickinson and Co., Franklin Lakes, NJ) and then macerated for $60 \mathrm{~s}$ in a stomacher (model 400C; Seward, Cincinnati, OH). Ten milliliters of the homogenous mixture was transferred to a $15-\mathrm{mL}$ conical tube, serially diluted $(1: 10)$ as needed in sterile 
$0.1 \%$ (wt/wt) peptone water, and then spread plated onto Modified Oxford (Becton, Dickinson and Co.) agar plates plus $100 \mu \mathrm{L} / \mathrm{mL}$ of rifampicin $\left(\mathrm{MOX}^{\text {rif }}\right)$. To recover sublethally pressure-injured cells of $L$. monocytogenes, the homogeneous mixture was serially diluted in sterile $0.1 \%$ peptone water, spread plated onto BHI agar (Becton, Dickinson and Co.), and then incubated at $37^{\circ} \mathrm{C}$ for $2 \mathrm{~h}$. After incubation, ca. $10 \mathrm{~mL}$ of $\mathrm{MOX}^{\text {rif }}$ was overlaid on the BHI agar, and then plates were incubated at $37^{\circ} \mathrm{C}$ for $48 \mathrm{~h}$ (Kang and Fung, 1999).

All plates were incubated at $37^{\circ} \mathrm{C}$ for $48 \mathrm{~h}$ and typical L. monocytogenes colonies were counted manually. Bacterial numbers were expressed as the logarithm of colony-forming units per gram. The detection limit was $<0.91 \log _{10} \mathrm{cfu} / \mathrm{g}$. The extent of sublethal injury was calculated as the percentage of the raw number of cells injured (Gurtler et al., 2010):

$\%$ injury $=$

$\left(1-\frac{\text { raw number of cells recovered on selective media }}{\text { raw number of cells recovered on non-selective media }}\right) \times 100 \%$.

\section{Enumeration of Endogenous Microorganisms}

Enumeration of the endogenous microflora in pathogen-free samples of QF was performed as previously described (Renye et al., 2008). High-hydrostaticpressure-processing-treated QF samples were analyzed after storage at 4 or $10^{\circ} \mathrm{C}$ for $1,7,28,56$, and $84 \mathrm{~d}$. A 10-g QF sample was homogenized in $90 \mathrm{~mL}$ of sodium citrate $(2 \%)$ using a stomacher $(230 \mathrm{rpm}$ for $2 \mathrm{~min}$; model 400C; Seward) and serial 10-fold dilutions of the homogenate were prepared in $0.1 \%$ peptone water. Plate count agar (Oxoid Ltd., Basingstoke, UK) and oxytetracycline glucose yeast extract (OGYE) agar base (Difco Laboratories Inc., Detroit, MI) containing $0.1 \%$ oxytetracycline (Calbiochem, San Diego, CA) were spread plated with $100 \mu \mathrm{L}$ of each dilution. Plate count agar plates were incubated at $30^{\circ} \mathrm{C}$ for $48 \mathrm{~h}$ and $5^{\circ} \mathrm{C}$ for up to $14 \mathrm{~d}$; and OGYE agar plates were incubated at $25^{\circ} \mathrm{C}$ for $72 \mathrm{~h}$. Bacterial colonies were counted on duplicate plates for each dilution and the reported counts were the averages of 3 independent QF cheeses. The limit of detection was $2.0 \log _{10} \mathrm{cfu} / \mathrm{g}$ of QF. Two representatives for each colony morphology observed were grown in BHI broth (Difco Laboratories Inc.) and used as a template for PCR amplification of the $16 \mathrm{~S}$ rRNA gene using the eubacterial oligonucleotide primers EubA and EubB (Cottrell and Kirchman, 2000). The 1.6-kb DNA fragment was sequenced with an ABI Prism 3730 DNA analyzer (PerkinElmer Inc., Wellesley, MA). The bacterial species were identified by comparing the $16 \mathrm{~S}$ rRNA sequences with those available in
GenBank using the National Center for Biotechnology Information BLAST search program (http://www.ncbi. nlm.nih.gov/BLAST/).

\section{Scanning Electron Microscopy}

Samples of QF were prepared in thin sections approximately $5 \times 5 \times 10 \mathrm{~mm}$ for scanning electron microscopy analysis. Squares measuring $2 \times 2 \mathrm{~mm}$ were marked on the surfaces of select samples with a pen. These squares were surface inoculated with L. monocytogenes (ON treatment) and then treated by HPP at 200, 400, and $600 \mathrm{MPa}$. The samples were then placed in a covered polystyrene nonpyrogenic Petri dish (no. 353004; BD Falcon, Franklin Lakes, NJ) and 10\% glutaraldehyde (catalog no. 16210; Electron Microscopy Sciences, Fort Washington, PA) in a $0.1 \mathrm{M}$ imidazole reagent (IMID) buffer (catalog no. 16905; Electron Microscopy Sciences) was applied to the squares and allowed to fix for $1 \mathrm{~h}$. Then, the samples were thin sliced to reduce sample volume while retaining the surface of interest on the cheese. Three milliliters of $2.5 \%$ glutaraldehyde/0.1 $M$ IMID buffer was additionally added to the plates and allowed to fix overnight.

Samples were then washed in $10 \mathrm{~mL}$ of $0.1 \mathrm{M}$ IMID buffer twice for $1.5 \mathrm{~h}$ each the next day. Samples were then processed through an ethanol dehydration series of $50 \%$ (vol/vol) ethanol twice for $2 \mathrm{~h}$ (Warner-Graham Co, Cockeysville, MD) and $80 \%$ ethanol 3 times for 1 h each with an overnight hold at $80 \%$. The final $100 \%$ dehydration step was done 3 times for $2 \mathrm{~h}$ each. The scanning electron microscopy images were obtained using a scanning electron microscope (Quanta 200 field emission scanning electron microscope; FEI Co., Hillsboro, OR).

\section{Statistical Analysis}

In phase II of this study, a SAS ANOVA (version 9.12; SAS Institute Inc., Cary, NC) was used to analyze the growth data to determine the effects and interactions of type of treatments (IN vs. ON), temperature $\left(4\right.$ or $\left.10^{\circ} \mathrm{C}\right)$, time of treatments $(3,10$, or $20 \mathrm{~min})$, and days of storage $(0,7,14,28,42$, or $60 \mathrm{~d})$ using PROC MIXED. Fisher's least significant difference (LSD) was used to test for significant differences at the $P=0.05$ significance level.

\section{RESULTS AND DISCUSSION}

\section{Phase I}

Thermal Inactivation of L. monocytogenes in $Q \boldsymbol{F}$. Little information is available on thermal inacti- 
vation of bacteria in soft cheeses because heat-induced quality changes tend to occur at temperatures $\geq 40$ to $50^{\circ} \mathrm{C}$ (Capellas et al., 2000; López-Pedemonte et al., 2007), which are required for inactivation. Heat treatment at $63^{\circ} \mathrm{C}$ for 5 min of a brined white cheese with a production procedure similar to that of $\mathrm{QF}$ resulted in ca. $1.5 \log _{10} \mathrm{cfu} / \mathrm{g}$ reduction of L. innocua (Al-Holy et al., 2012). Those authors did not indicate if heat treatment affected the quality attributes of the cheese. In our study, heat treatment of the packaged slices of $\mathrm{QF}$ at $40^{\circ} \mathrm{C}$ also resulted in a ca. $1.5 \log _{10}$ reduction in the 5-strain cocktail of L. monocytogenes. However, significant wheying-off was observed and the QF was found to have different textural and rheological properties compared with a control at $20^{\circ} \mathrm{C}$ (Van Hekken et al., 2013).

Temperature-Pressure Inactivation of $L$. monocytogenes in $\mathbf{Q F}$. The phase-I studies were conducted to determine the optimal pressure-temperaturehold time combinations for inactivating L. monocytogenes in QF. Each pressurization was accompanied by an increase in $\mathrm{QF}$ and pressurizing fluid temperatures compared with their initial temperatures of 20 or $40^{\circ} \mathrm{C}$. The increase in temperature may be attributed to adiabatic compression generated during the come-up time (i.e., the time that the target pressure was reached). The come-up times at 200,400, or $600 \mathrm{MPa}$ were 1.3 , 1.9 , and $2.5 \mathrm{~min}$, respectively, with corresponding maximum QF temperatures of $26.3,35.7$, and $43.2^{\circ} \mathrm{C}$ from an initial $\mathrm{QF}$ temperature of $20^{\circ} \mathrm{C}$. The average increase in the $\Delta T / \Delta P$ was about $3.6^{\circ} \mathrm{C} / 100 \mathrm{MPa}$. The maximum temperatures of $\mathrm{QF}$ upon pressurization at 200,400 , or $600 \mathrm{MPa}$, from the initial temperature of $40^{\circ} \mathrm{C}$, were $48.7,59.4$, and $67.7^{\circ} \mathrm{C}$, respectively, corresponding to an increase in $\Delta T / \Delta P$ of about $4.6^{\circ} \mathrm{C} / 100$ MPa.

The $\Delta T / \Delta P$ is a function of temperature and the physical properties of QF, as shown in Equation 1. Van Hekken et al. (2013) reported that QF contains an average of $56.1 \%$ moisture, $15.4 \%$ protein, $22.3 \%$ fat, $2.9 \%$ lactose, and $3.3 \%$ ash, with about a $2.0 \%$ salt content. It could initially be assumed that because of its high moisture content of $56.1 \%$, the $\Delta T / \Delta P$ for $\mathrm{QF}$ would agree with those for water, with calculated values of $2.9^{\circ} \mathrm{C} / 100 \mathrm{MPa}$ at $20^{\circ} \mathrm{C}$ and $3.4^{\circ} \mathrm{C} / 100 \mathrm{MPa}$ at $40^{\circ} \mathrm{C}$ (Harvey et al., 2004). However, fats have higher $\Delta T /$ $\Delta P$ than those for water, with reported values of up to $8.7^{\circ} \mathrm{C} / 100 \mathrm{MPa}$ (Rasanayagam et al., 2003). Thus, the higher $\Delta T / \Delta P$ for fat would raise the overall $\Delta T /$ $\Delta P$ for cheese, as the other components have $\Delta T / \Delta P$ similar to that of water (Trujillo et al., 2002). There may also be a small contribution to the higher value of $\Delta T / \Delta P\left(4.6^{\circ} \mathrm{C} / 100 \mathrm{MPa}\right)$ for $\mathrm{QF}$ with an initial tem- perature of $40^{\circ} \mathrm{C}\left(3.6^{\circ} \mathrm{C} / 100 \mathrm{MPa}\right)$ versus $20^{\circ} \mathrm{C}$ due to the loss of whey associated with preheating the cheese before HPP and a loss of $2 \%$ of whey during processing, which tended to increase with increasing pressure, and would shift the distribution of the components in the cheese (Van Hekken et al., 2013).

The levels of L. monocytogenes for pressures of 200, 400 and $600 \mathrm{MPa}$, with holding times of 5, 10, 15, and 20 min for initial cheese temperatures of 20 and $40^{\circ} \mathrm{C}$ are shown in Figures 1a and 1b, respectively. Examination of the curves for QF treated at $200 \mathrm{MPa}$ and 20 and $40^{\circ} \mathrm{C}$ show what is often interpreted as shoulders at each of the hold times. This pressure, with adiabatic temperature increase of $26.3^{\circ} \mathrm{C}$, had no effect $(P>0.05)$ on inactivation of $L$. monocytogenes relative to the control (Figure 1a). For treatment at $200 \mathrm{MPa}$ for QF with initial temperature of $40^{\circ} \mathrm{C}$, the adiabatic temperature increase of $48.7^{\circ} \mathrm{C}$ (Figure 1b) did not contribute to an increase in reduction of $L$. monocytogenes levels relative to the 1.5-log reduction that occurred upon heating the inoculated $\mathrm{QF}$ from 20 to $40^{\circ} \mathrm{C}$ before pressurization, even at the highest hold time of $20 \mathrm{~min}$.

At $400 \mathrm{MPa}$ (Figure 1a), with QF adiabatic temperature increase of $35.7^{\circ} \mathrm{C}$, a log-linear decrease in counts with holding time was noted, with an overall 1.78-log reduction in L. monocytogenes numbers at a hold time of $20 \mathrm{~min}$ (Figure 1a). The synergistic effects of pressure at $400 \mathrm{MP}$ and adiabatic temperature increase of $59.4^{\circ} \mathrm{C}$ are shown in comparison in Figure $1 \mathrm{~b}$, with a log-linear decrease in L. monocytogenes counts of 2 log at a 5-min hold time. When the hold time was increased to $15 \mathrm{~min}$, a tailing effect was observed, with only an additional 1.25-log reduction in pathogen numbers, reaching below the minimum level of detection of 0.91 log. At $600 \mathrm{MPa}$, at initial QF temperatures of 20 and $40^{\circ} \mathrm{C}$ (Figures $1 \mathrm{a}$ and $1 \mathrm{~b}$ ), L. monocytogenes numbers were reduced by 4.6 and 3.25, with final counts reaching the minimum level of detection at the lowest hold time of 5 min.

Although HPP processing conditions of $200 \mathrm{MPa}$ were generally ineffective in reducing $L$. monocytogenes on QF, pressures of at least $300 \mathrm{MPa}$ applied for $5 \mathrm{~min}$ with temperatures in the range from 5 to $25^{\circ} \mathrm{C}$ have been found to reduce yeast and molds, as these microorganisms are less resistant to HPP than gram-positive bacteria such as Listeria spp. (Martínez-Rodríguez et al., 2012). The susceptibility of L. monocytogenes to pressure, measured by the numbers of sublethally injured cells, was not determined for QF at an initial temperature of $20^{\circ} \mathrm{C}$ in this phase of the current study. For QF with an initial temperature of $40^{\circ} \mathrm{C}$, sublethally injured L. monocytogenes were not detected when $\mathrm{QF}$ was treated at $400 \mathrm{MPa}$ and a hold time $\geq 15 \mathrm{~min}$, or at 

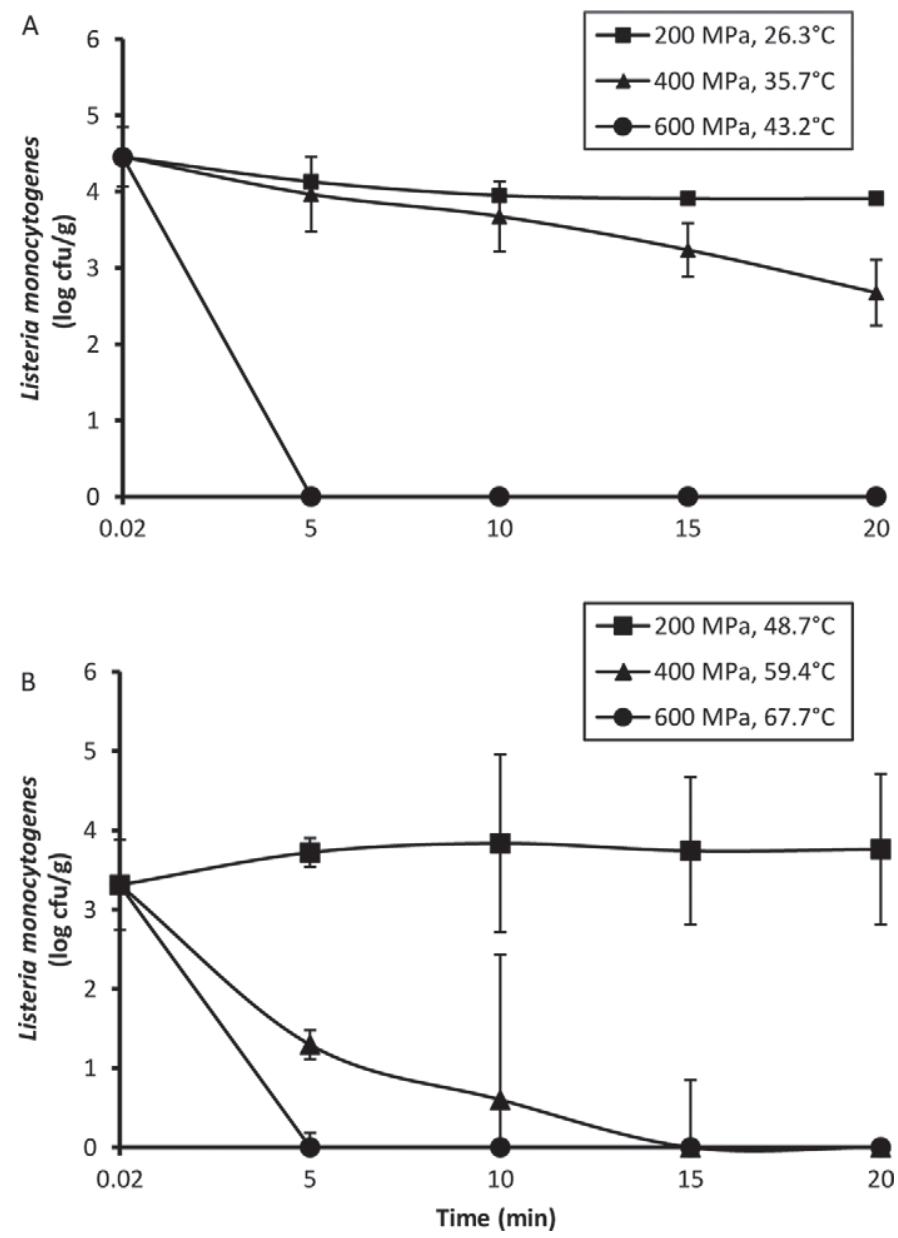

Figure 1. Effect of pressure on logarithmic reduction of 5-strain cocktail of Listeria monocytogenes (a) for initial Queso Fresco (QF) temperature of $20^{\circ} \mathrm{C}$ and (b) for initial $\mathrm{QF}$ temperature of $40^{\circ} \mathrm{C}$. The temperature of $\mathrm{QF}$ upon pressurization is given in the legend. The error bars represent SD. Some error bars fall within the plot symbols and are not visible.

$600 \mathrm{MPa}$ and all hold times. Thus, these temperaturepressure combinations were lethal to $L$. monocytogenes on QF.

For most bacteria, higher pressures and temperatures and longer hold times are necessary for achieving reductions greater than $5 \mathrm{log}$ in cheese (Martínez-Rodríguez et al., 2012.) However, in the case of QF, temperatures $\geq 40^{\circ} \mathrm{C}$ and the pressure can negatively affect the sensory properties, causing whey losses (Capellas et al., 2000; Van Hekken et al., 2013), subtle textural changes (Sandra et al., 2004; Van Hekken et al., 2013), or severe changes in texture. These negative effects have been reported for a low-pH QF made using starter cultures, changing the signature properties of the cheese (Hnosko et al., 2012).

Microstructure. In addition to the use of nonspecific media, scanning electron microscopy is useful for indicating if microorganisms have been sublethally injured by physical treatments such as HPP (Ritz et al., 2001). Scanning electron micrographs at 5,000× magnification, showing $L$. monocytogenes on the surface of QF sections with an initial temperature of $20^{\circ} \mathrm{C}$, after treatment at 200,400 , or $600 \mathrm{MPa}$, for a hold time of 5 min are shown in Figure 2a. Prior to treatment, the surfaces of $L$. monocytogenes cells were smooth. The cell surface remained smooth after treatment at 200 $\mathrm{MPa}$, but showed surface damage after treatment at $400 \mathrm{MPa}$. After treatment at $600 \mathrm{MPa}$, the cell showed increased surface damage in the form of bud scars and appeared to shrink. At a hold time of 20 min (Figure $2 \mathrm{~b})$, cells of L. monocytogenes appeared to be intact after treatment at $200 \mathrm{MPa}$, but bud scars were evident on the cell surface, indicating that the membrane was disrupted or that a loss of membrane integrity occurred. Although the disruption was apparent, it was not lethal to the cells, as the decrease in pathogen levels at this pressure compared with the control (Figure 1a) was considered not significant $(P>0.05)$. According to Ritz et al. (2001), the number of buds is about proportional to pressure. At 400 and $600 \mathrm{MPa}$, bud scars were also evident on the intact cells and a few cells appeared to have lost their morphological characteristics. However, due to the qualitative nature of this approach it was difficult to discern if a difference existed in the number of cell disruptions at 400 versus $600 \mathrm{MPa}$. Figure 1a shows that pathogen levels were reduced to below the detection level after 5 min of HPP treatment at $600 \mathrm{MPa}$, whereas surviving cells were apparent after treatment at $400 \mathrm{MPa}$ for $20 \mathrm{~min}$. The differences in temperature due to adiabatic compression at $400 \mathrm{MPa}$ (i.e., $35.7^{\circ} \mathrm{C}$ ) and at $600 \mathrm{MPa}$ (i.e., $43.2^{\circ} \mathrm{C}$ ) were not likely to account for the differences in L. monocytogenes numbers after a hold time of 20 min.

The substrate, composition, and water activity may affect the response of microorganisms to HPP treatment (Considine et al., 2008; Martínez-Rodríguez et al., 2012). The changes in the QF substrate as the applied pressure was increased are apparent in Figures $2 \mathrm{a}$ and $2 \mathrm{~b}$. As described previously (Van Hekken et al., 2013), the increasing pressures from 200 to $600 \mathrm{MPa}$ resulted in a progressive fusing of the protein matrix with individual micelles fusing into thicker strands. These changes were accompanied by increasing wheying-off observed on the surface of the cheese. It is doubtful that the increased microbial susceptibility to HPP at the higher pressures was directly affected by changes in the substrate relative to the high pressures applied because $L$. monocytogenes was on the surface and not the interior of QF. However, the increases in pressure altered the substrate, thereby forcing whey from the interior of the cheese to the surface. This alteration 
(a)
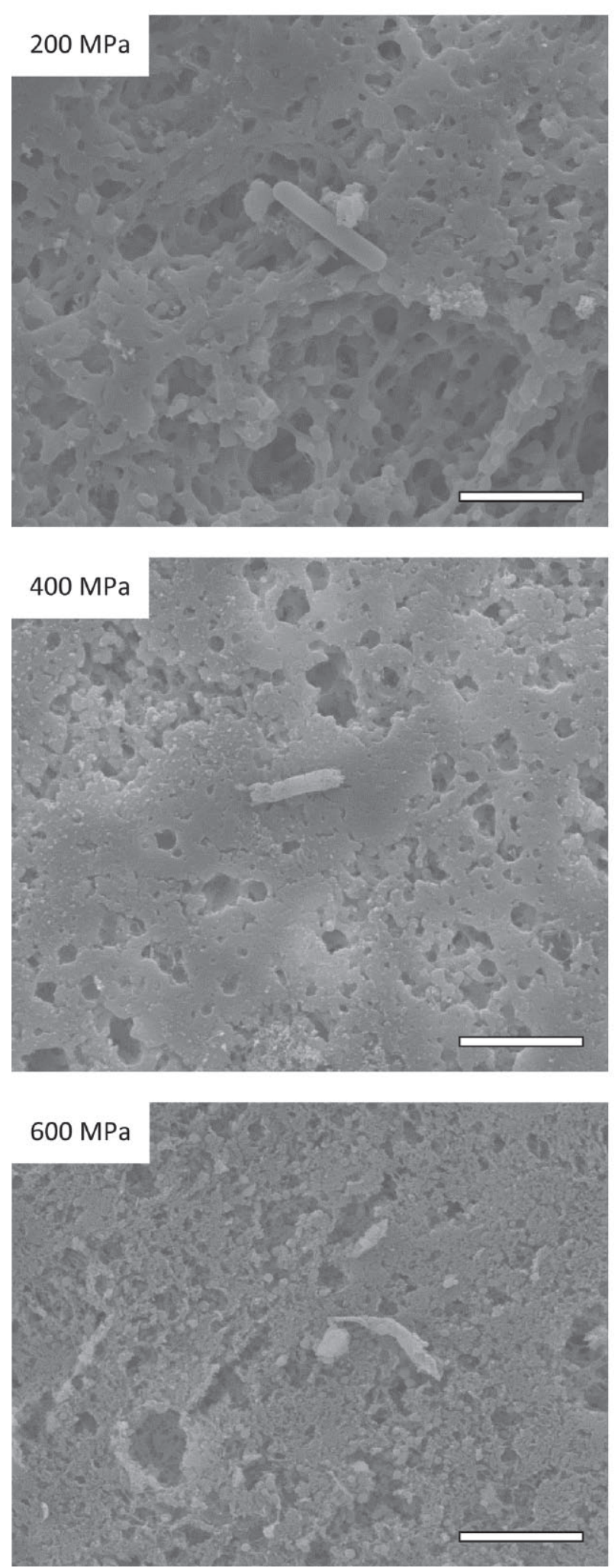

(b)
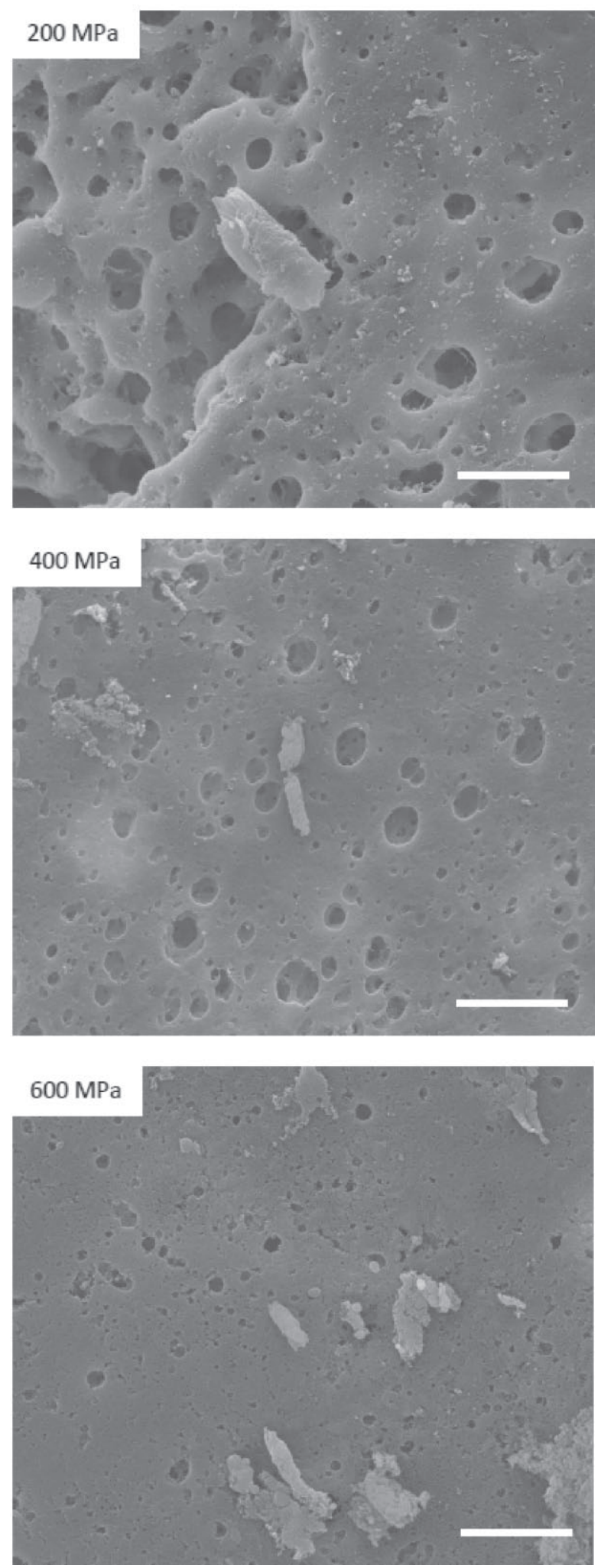

Figure 2. Scanning electron micrographs of Queso Fresco (QF) surface inoculated with ca. $4.5 \log _{10}$ cfu of Listeria monocytogenes/g of QF and then processed at 200,400, and $600 \mathrm{MPa}$, respectively. Micrographs are at 5,000× magnification. The scale bars represent $5 \mu \mathrm{m}$. At 200, 400, and $600 \mathrm{MPa}$, QF temperatures during pressurization were $26.3,35.7$, and $43.2^{\circ} \mathrm{C}$, respectively. (a) Hold time of 5 min; (b) hold time of 20 min. 
may affect inactivation of $L$. monocytogenes, as low water activity environments support the survival of microorganisms due to reduced permeability of the cell membrane (Smelt, 1998; Martínez-Rodríguez et al., 2012).

Scanning electron microscopy was also conducted for $\mathrm{QF}$ at $20^{\circ} \mathrm{C}$ that was surface inoculated with $L$. monocytogenes and HPP treated at $600 \mathrm{MPA}$ with hold times of $3,5,10,15$, and $20 \mathrm{~min}$ (not shown). The results showed damage to L. monocytogenes cells even at the lowest hold times, with no apparent differences in the extent of damage with increasing hold time. Scanning electron microscopy of $\mathrm{QF}$ at $40^{\circ} \mathrm{C}$ was attempted but $L$. monocytogenes cells were not found on the surface after treatment at any of the pressures.

Ritz et al. (2001) observed that pressurized cells did not behave as live or dead cells, even though they gave the appearance of total inactivation through cell count determination. They suggested that reversible damage was a possibility due to the variability in the extent of injury and cell heterogeneity. This observation suggests that assessment of HPP for food safety purposes should be followed by storage studies over the shelf life of a food product to ensure that populations of pathogens, such as L. monocytogenes, are inactivated and not injured.

\section{Phase II}

Storage Study of L. monocytogenes in and on $Q \boldsymbol{F}$ Slices. The storage study was conducted using QF samples with an initial temperature of $20^{\circ} \mathrm{C}$ that were treated at $600 \mathrm{MPa}$ and held for 3, 10, or 20 min at a temperature of $43.2^{\circ} \mathrm{C}$ following adiabatic compression. This pressure-temperature combination was found to be the most effective for inactivation of $L$. monocytogenes on the surface of QF while preserving the sensory and textural properties of QF (Van Hekken et al., 2013). The initial levels of L. monocytogenes-inoculated IN and $\mathrm{ON}$ slices of QF were $6.91 \pm 0.15$ and $4.85 \pm 0.21$ $\log _{10} \mathrm{cfu} / \mathrm{g}$, respectively, to simulate environmental contamination after pasteurization (Leggett et al., 2012). The viability of $L$. monocytogenes following treatment at $600 \mathrm{MPa}$ for 3,10 , or $20 \mathrm{~min}$ was followed by storage for $60 \mathrm{~d}$ at a refrigeration temperature of $4^{\circ} \mathrm{C}$ and abuse temperature of $10^{\circ} \mathrm{C}$. The L. monocytogenes levels after HPP correspond to a time of 0 in Figures 3a to 3f. High-hydrostatic-pressure processing treatment at 600 MPa with a hold time of 3 min showed an average 3.31 $\pm 1.20 \log$ reduction for the IN treatment QF and 4.12 $\pm 0.81 \mathrm{log}$ reduction for the $\mathrm{ON}$ treatment.

For the IN treatment cheese, L. monocytogenes increased from $3.60 \pm 1.05 \log _{10} \mathrm{cfu} / \mathrm{g}$ on d 0 of storage at $4^{\circ} \mathrm{C}$ to $8.08 \pm 0.20 \log _{10} \mathrm{cfu} / \mathrm{g}$ at $60 \mathrm{~d}$ of storage (Figure 3a). In comparison, L. monocytogenes for the ON treatment increased from $0.73 \pm 0.60$ to $8.40 \pm 0.19 \log _{10}$ $\mathrm{cfu} / \mathrm{g}$ (Figure $3 \mathrm{~b}$ ), showing no difference $(P>0.05)$ in pathogen viability between treatments, even though the initial counts of L. monocytogenes were greater for the IN samples on $d$. Calculations of the percentage of injured cells for the IN and ON treatments for up to 2 wk of storage are shown in Table 1 for 1, 7, and $14 \mathrm{~d}$ of storage at $4^{\circ} \mathrm{C}$ or $1 \mathrm{~d}$ after $10^{\circ} \mathrm{C}$. Regardless of treatment, at $4^{\circ} \mathrm{C}$, most of the cells of $L$. monocytogenes were injured. A decrease in the percentage of injured cells was noted as storage time extended to $2 \mathrm{wk}$. By d 14 of storage at $10^{\circ} \mathrm{C}$ (Figures $3 \mathrm{a}$ and $3 \mathrm{~b}$ ), little difference $(P>0.05)$ was observed in $L$. monocytogenes counts for $\mathrm{QF}$ or lag time $(P<0.05)$ for either the IN and $\mathrm{ON}$ treatments, as the higher temperature facilitated growth of the pathogen. By $28 \mathrm{~d}$, the value of the $L$. monocytogenes counts for the IN treatments at both storage temperatures began to converge but for the $\mathrm{ON}$ treatments, the data at 4 and $10^{\circ} \mathrm{C}$ did not converge until $42 \mathrm{~d}$, in both cases indicating that HPP followed by storage at $4^{\circ} \mathrm{C}$ cannot control growth of the pathogen. Overall, although QF was treated at 600 MPa for a 3-min hold time, L. monocytogenes numbers were within $1.0 \log$ after $42 \mathrm{~d}$ of the average of $8.24 \pm$ $0.41 \log _{10} \mathrm{cfu} / \mathrm{g}$ noted for QF at $60 \mathrm{~d}$ of storage.

Increasing the hold time to $10 \mathrm{~min}$ after pressurization at $600 \mathrm{MPa}$ resulted in a decrease in L. monocytogenes to below detection levels for the IN and ON treatments at $\mathrm{d} 0$ (Figures $3 \mathrm{c}$ and $3 \mathrm{~d}$, respectively). During storage at $4^{\circ} \mathrm{C}$, growth of L. monocytogenes was observed by $\mathrm{d} 7$ for the IN treatment but it appeared that there was a 7 -d lag in growth for the ON treatment. Most of the cells for the IN (97.2\%) and the ON $(96 \%)$ treatments were injured $1 \mathrm{~d}$ following HPP treatment. After $2 \mathrm{wk}$, there was a decrease in the number of injured cells (Table 1) for the IN treatment and, as indicated in Figure 3c, a steady growth of L. monocytogenes was observed; but for the ON treatment, a high percentage of cells $(97.7 \%)$ remained injured after 2 wk, with growth of L. monocytogenes delayed for $1 \mathrm{wk}$ (Figure 3d). Little difference was observed in the trends observed for viability of L. monocytogenes for the IN or ON treatments when stored at $10^{\circ} \mathrm{C}$.

Increasing the hold time to 20 min after pressurization to $600 \mathrm{MPa}$ resulted in a decrease in L. monocytogenes levels to below the detection limit for both the IN and ON treatments (Figures 3e and 3f). An increase in the lethality of the process compared with the 3 - and 10 -min hold times was indicated by the $0 \%$ injured cells for the IN treatment and $29 \%$ for the ON treatment (Table 1). Regardless of the apparent lethality for the IN process on d 0 , growth of L. monocytogenes occurred by 2 wk, after an apparent lag time of 1 wk (Figure 3e). 

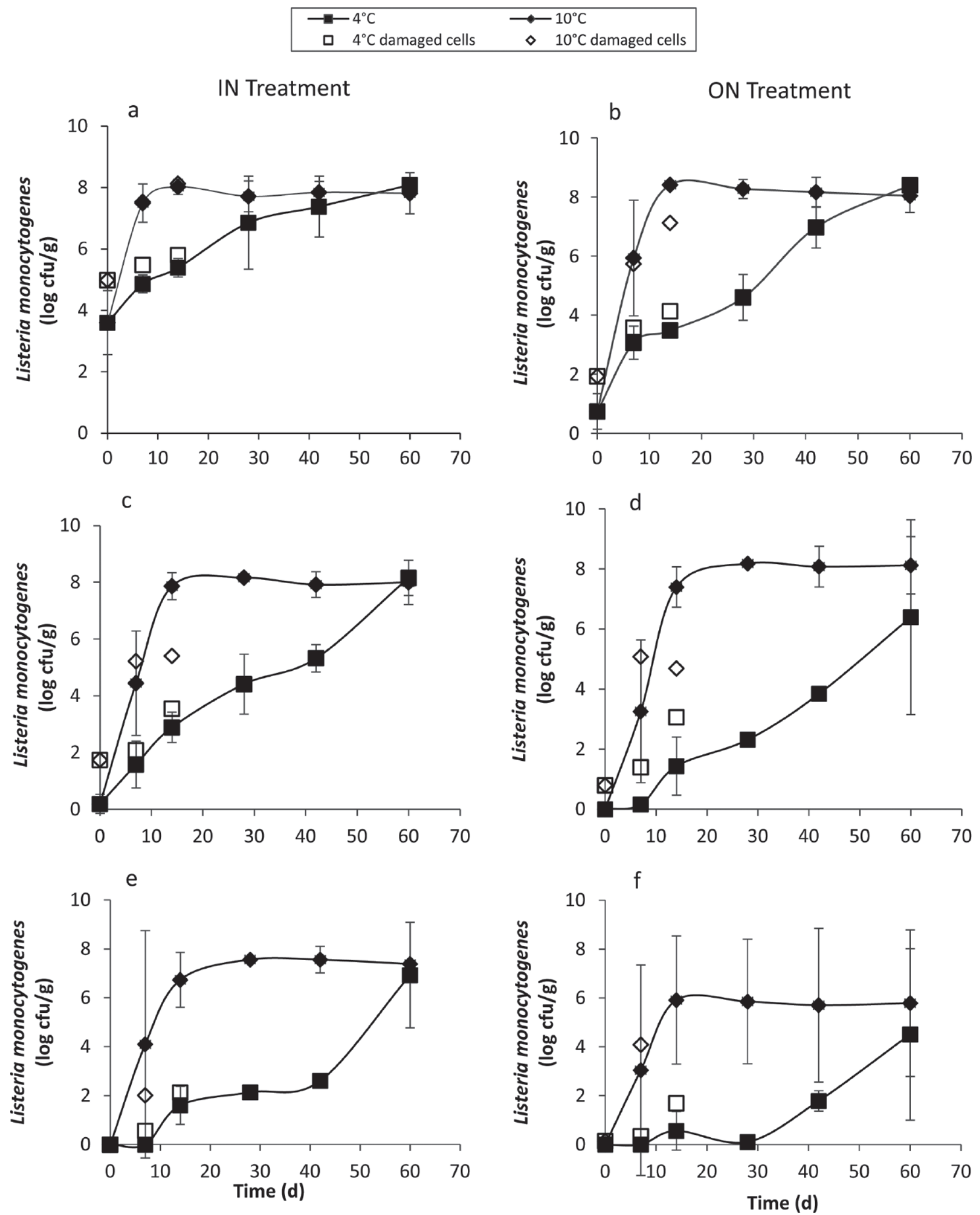

Figure 3. Growth of Listeria monocytogenes in storage at 4 or $10^{\circ} \mathrm{C}$ on Queso Fresco $(\mathrm{QF})$ slices after high-hydrostatic-pressure processing (HPP) treatment at $600 \mathrm{MPa}$, initial cheese temperature of $20^{\circ} \mathrm{C}$, and hold times of (a) 3, (c) 10, and (e) 20 min for the IN treatment (L. monocytogenes inoculated in QF curds, formed into a cheese block and sliced), and (b) 3, (d) 10, and (f) 20 min for the ON treatment (L. monocytogenes inoculated on QF slices). The error bars represent SD. 
Table 1. Percentage injury of 5-strain Listeria monocytogenes inoculated in the curds (IN) or on the slices $(\mathrm{ON})$ of Queso Fresco $(\mathrm{QF})$, following high-hydrostatic-pressure processing (HPP) treatment at $600 \mathrm{MPa}$, as a function of storage at 4 or $10^{\circ} \mathrm{C}$ and storage time

\begin{tabular}{|c|c|c|c|c|c|c|}
\hline \multirow[b]{3}{*}{ HPP hold time (min) } & \multicolumn{6}{|c|}{ Storage time $(\mathrm{d})$} \\
\hline & \multicolumn{3}{|c|}{$\mathrm{IN}^{1}$} & \multicolumn{3}{|c|}{$\mathrm{ON}^{2}$} \\
\hline & 1 & 7 & 14 & 1 & 7 & 14 \\
\hline \multicolumn{7}{|l|}{$\overline{4^{\circ} \mathrm{C} \text { storage }}$} \\
\hline 3 & 95.1 & 76.0 & 61.1 & 93.7 & 69.1 & 78.1 \\
\hline 10 & 97.2 & 68.8 & 78.1 & 96.0 & 94.3 & 97.7 \\
\hline 20 & 0.0 & 72.5 & 69.8 & 29.2 & 54.3 & 92.8 \\
\hline \multicolumn{7}{|l|}{$10^{\circ} \mathrm{C}$ storage } \\
\hline 3 & 95.8 & & & 93.7 & & \\
\hline 10 & 97.2 & & & 84.2 & & \\
\hline 20 & 0.0 & & & & & \\
\hline
\end{tabular}

Injured cells were detected after 7 and $14 \mathrm{~d}$. Although the ON process showed that $29 \%$ of cells were injured on $\mathrm{d} 0$ and cells were injured on $\mathrm{d} 7$ and 14, no growth of L. monocytogenes occurred until d 28 (Figure $3 \mathrm{f}$ ). For the IN treatment and storage at $10^{\circ} \mathrm{C}$, the maximum growth of L. monocytogenes was $7.51 \pm 0.10 \log _{10} \mathrm{cfu} / \mathrm{g}$ and was achieved at $28 \mathrm{~d}$. The $\mathrm{ON}$ treatment stored at $10^{\circ} \mathrm{C}$ showed maximum growth of L. monocytogenes of $5.82 \pm 2.62 \log _{10}$ after $14 \mathrm{~d}$ and was not significantly different than the ON treatment $(P<0.05)$.

In general, as HPP hold time was increased to 20 min, a decrease in the numbers of injured cells occurred because of the increased lethality of the treatment. At $4^{\circ} \mathrm{C}$, the growth rate for the IN treatment was approximately twice that of the ON treatment and a $7-\mathrm{d}$ delay in growth was not observed for the IN treatment, except for the 20-min hold time. For the ON treatment, lag times in growth of L. monocytogenes at $4^{\circ} \mathrm{C}$ were observed after the 10- and 20-min hold times, indicating that HPP treatment for L. monocytogenes on the surface of QF appeared to be more effective than that for cells on the interior, showing the sensitivity of the pathogen to subtle changes in environment even within the same sample during processing. As indicated in Van Hekken et al. (2012), unpressed QF loses approximately 1.2 to $1.7 \%$ moisture because of syneresis (wheyingoff) during storage. With HPP, the moisture content of the interior of QF decreases further, with increases in pressure and hold time resulting in visible wheyingoff on the surface of packaged QF, due to structural changes shown in Figure 2. The increased moisture at the surface of the cheese enhances injury and inactivation (Smelt 1998; Martínez-Rodríguez et al., 2012). The $\mathrm{pH}$ and mineral content shifts throughout the cheese were not followed but may have also contributed to the differences in lag times between the IN and ON treatments, as described in Considine et al. (2008).
Levels of Indigenous Bacteria. As reported previously, the total aerobic mesophilic counts for pathogen-free QF cheeses were $3.5 \pm 0.1$ and $3.4 \pm 0.3$ $\log _{10} \mathrm{cfu} / \mathrm{g}$ after $1 \mathrm{~d}$, and $6.3 \pm 0.8$ and $7.7 \pm 0.5 \log _{10}$ $\mathrm{cfu} / \mathrm{g}$ after $84 \mathrm{~d}$, when stored at 4 and $10^{\circ} \mathrm{C}$, respectively (Leggett et al., 2012). High-hydrostatic-pressure processing treatment at $600 \mathrm{MPa}$ for $3 \mathrm{~min}$ or $10 \mathrm{~min}$ decreased the mesophilic counts to below the detection level of $2 \log _{10} \mathrm{cfu} / \mathrm{g}$ (Figure 4A, d 1). These results are in agreement with previous reports that showed that $\mathrm{HPP}$ treatment at >500 $\mathrm{MPa}$ effectively reduced the number of microbial contaminants in Cheddar cheese (O'Reilly et al., 2000) and the number of starter lactococci in fresh curd cheese (Daryaei et al., 2006). Mesophilic counts remained at or below the level of detection for up $56 \mathrm{~d}$ in most HPP-treated QF samples stored at $4^{\circ} \mathrm{C}$, with the exception of one 3 -min HPP-treated cheese showing $3.2 \log _{10}(56 \mathrm{~d})$ and one 10-min HPPtreated cheese showing $3.4 \log _{10} \mathrm{cfu} / \mathrm{g}(28 \mathrm{~d})$. Following $84 \mathrm{~d}$ of storage at $4^{\circ} \mathrm{C}$, the indigenous microflora was not detected in 2 of the $3 \mathrm{QF}$ samples that were treated for $10 \mathrm{~min}$, with the third cheese having $4.2 \log _{10} \mathrm{cfu} / \mathrm{g}$. All QF samples that were HPP treated for $3 \mathrm{~min}$ had bacterial growth at $84 \mathrm{~d}$, with an average of $4.1 \pm 1.5$ $\log _{10} \mathrm{cfu} / \mathrm{g}$, which was $2 \log$ lower than the $6.3 \pm 0.8$ $\log _{10} \mathrm{cfu} / \mathrm{g}$ observed in nontreated QF samples (Leggett et al., 2012). A delay in the recovery and growth of aerobic mesophiles was previously reported for fresh cheeses stored at $4^{\circ} \mathrm{C}$ after HPP treatment at 300 or $400 \mathrm{MPa}$ for $5 \mathrm{~min}$ (Evert-Arriagada et al., 2012). However, HPP treatment at $\leq 400 \mathrm{MPa}$ did not decrease the initial load of aerobic mesophiles in fresh cheese and the bacterial load was similar to the control cheese by $\mathrm{d}$ 21 of storage (Evert-Arriagada et al., 2012), suggesting that the higher pressure used in the current study offers a significant advantage for increasing the shelf life of cheeses stored at $4^{\circ} \mathrm{C}$. 
For QF samples stored at $10^{\circ} \mathrm{C}$, the mesophilic counts remained at or below the level of detection on d 7 (Figure $4 \mathrm{~B}$ ). By d 28, bacterial growth was observed in 5 of the $6 \mathrm{QF}$ samples, with an average of $4.4 \pm 0.4$ and $4.3 \pm 0.7 \log _{10} \mathrm{cfu} / \mathrm{g}$ for the 3 - and 10-min HPP-treated cheeses, respectively. The bacterial load increased after $84 \mathrm{~d}$ of storage to $5.4 \pm 1.7$ and $6.0 \pm 0.8 \log _{10} \mathrm{cfu} / \mathrm{g}$ in the 3- and 10-min HPP-treated QF samples, but remained $2 \log _{10}$ lower than the untreated sample $\left(7.7 \pm 0.5 \log _{10}\right.$ $\mathrm{cfu} / \mathrm{g}$ stored at $\left.10^{\circ} \mathrm{C}\right)$. These results emphasize the importance of the storage temperature following HPP treatment, as the bacterial load in both HPP-treated cheeses stored at $10^{\circ} \mathrm{C}$ for $28 \mathrm{~d}$ was similar to what was observed in the 3-min HPP-treated QF stored at $4^{\circ} \mathrm{C}$ for $84 \mathrm{~d}$. Similar results were reported for HPP-treated fresh cheeses, where the bacterial load increased more rapidly when stored at 8 versus $4^{\circ} \mathrm{C}$ (Evert-Arriagada et al., 2012). Previously, we reported the identification of gram-negative contaminants, including Escherichia hermannii, Pseudomonas aeruginosa, and Enterobacter asburiae, in QF samples stored for $56 \mathrm{~d}$ at $4^{\circ} \mathrm{C}$, or $84 \mathrm{~d}$ at $10^{\circ} \mathrm{C}$ (Leggett et al., 2012). However, these bacterial species were not isolated from any of the HPP-treated QF samples, demonstrating the effectiveness of this technique against these contaminants. The bacterial species isolated from the HPP-treated QF samples included Enterococcus faecalis (99\% identity; GenBank accession no. HQ721277), Enterococcus durans (97\%; GenBank accession no. HQ6778261), Bacillus pumilus (99\%; GenBank accession no. HQ334985), Bacillus simplex (99\%; GenBank accession no. JF496520), Paenibacillus glucanolyticus (99\%; GenBank accession no. AB073189), and Micrococcus luteus (92\%; GenBank accession no. EU379264), which have all been previously identified as contaminants within milk and dairy foods (Ogier et al., 2004; Foulquié Moreno et al., 2006; Renye et al., 2008; Ivy et al., 2012). The identification of grampositive bacteria within the stored HPP-treated cheeses was expected, as they are generally considered more tolerant of high pressure than gram-negative bacteria, molds, and yeasts (Cheftel, 1995). Bacterial spores have been reported to withstand pressures of up to 1,000 MPa (Cheftel, 1995), which may explain why the Bacillus and Paenibacillus species persisted in HPP-treated QF samples. Due to the pressure tolerance of spores, other studies have shown that the use of additional hurdles, such as nisin (López-Pedemonte et al., 2003), with HPP treatment may improve the potential for inactivating spores within foods. The identification of $E$. faecalis and E. durans in the HPP-treated QF samples from the current study, along with previous reports that Enterococcus hirae was highly tolerant of pressure treatments up to $500 \mathrm{MPa}$ (Szczawiński et al., 2003; Fonberg-Broczek et al., 2005) suggests that enterococci,

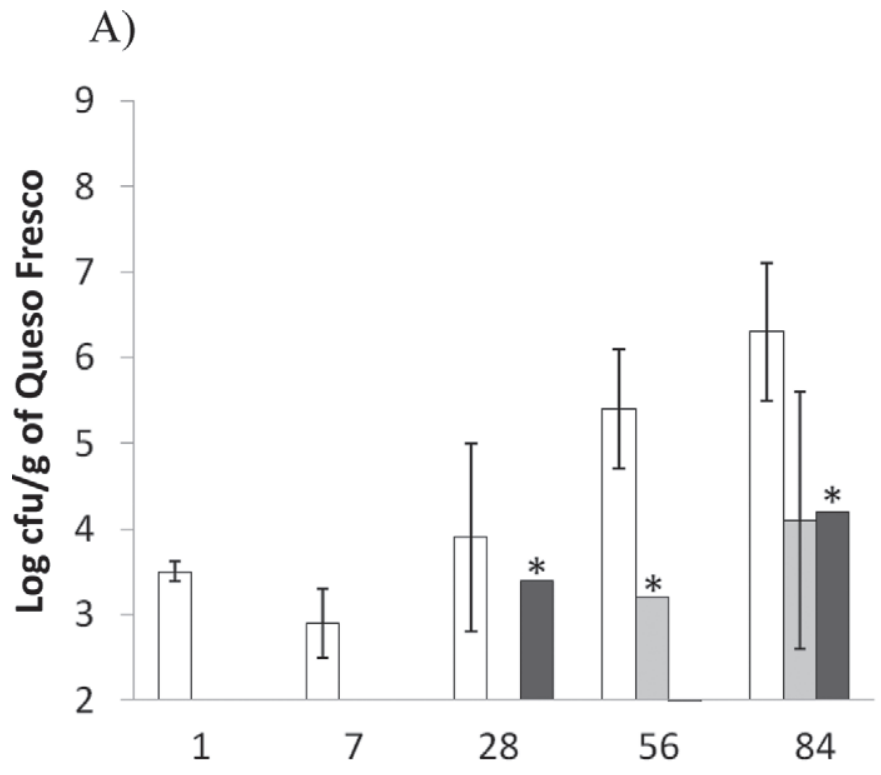

B)

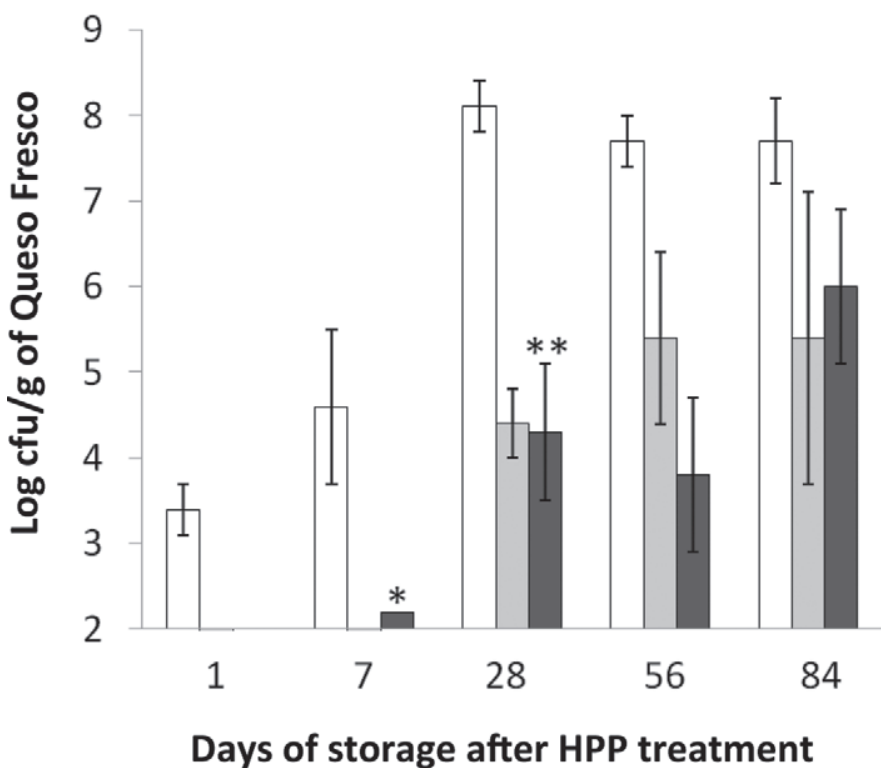

Figure 4. Total aerobic mesophilic bacterial counts in untreated (white bars), 3-min high-hydrostatic-pressure processing (HPP)treated (light gray), and 10-min HPP-treated (dark gray) Queso Fresco $(\mathrm{QF})$ stored at $4^{\circ} \mathrm{C}(\mathrm{A})$ or $10^{\circ} \mathrm{C}(\mathrm{B})$. Counts were the average of 3 independent cheese samples $\pm \mathrm{SD}$, with the limit of detection at $2 \log _{10} \mathrm{cfu} / \mathrm{g}$ of QF. Bars with a single asterisk $(*)$ are colony counts from $1 \mathrm{QF}$ sample; bars with 2 asterisks $(* *)$ are colony counts from 2 QF samples. Data shown as white bars were previously reported (Leggett et al., 2012).

in general, have a high pressure tolerance. Micrococcus luteus was also reported to have a high pressure tolerance with pure cultures having a similar tolerance level to spore formers Bacillus cereus and Bacillus subtilis (Arroyo et al., 1999). In a recent study, both enterococci and Micrococcaceae were shown to persist in an 
HPP-treated (at $600 \mathrm{MPa}$ ) raw milk cheese stored at $4^{\circ} \mathrm{C}$. Survival was dependent on the time of HPP treatment, as only Micrococcaceae were observed to survive for up to $240 \mathrm{~d}$ when pressure was applied after $5 \mathrm{wk}$ of ripening (Calzada et al., 2013). In the current study, storage of $\mathrm{QF}$ at $4^{\circ} \mathrm{C}$ was required to extend the shelf life of 3-min HPP-treated cheese to $56 \mathrm{~d}$, and 10-min HPP-treated cheese to $84 \mathrm{~d}$.

High-hydrostatic-pressure processing treatment for either 3 or 10 min was also sufficient to prevent the growth of psychrotrophic bacteria, molds, and yeasts in QF samples stored at either 4 or $10^{\circ} \mathrm{C}$ for up to 84 d. In untreated QF samples, psychrotrophic bacteria, including Stenotrophomonas spp., Pseudomonas fluorescens, and Enterobacter aerogenes, were detected at 56 $\mathrm{d}\left(4.5 \log _{10} \mathrm{cfu} / \mathrm{g}\right)$ when stored at $4^{\circ} \mathrm{C}$, and $84 \mathrm{~d}(5.2$ $\left.\log _{10} \mathrm{cfu} / \mathrm{g}\right)$ when stored at $10^{\circ} \mathrm{C}$; and yeast and molds (growth on OGYE agar) were detected by $28 \mathrm{~d}(2.7$ $\left.\log _{10} \mathrm{cfu} / \mathrm{g}\right)$ and $56 \mathrm{~d}\left(2.4 \log _{10} \mathrm{cfu} / \mathrm{g}\right)$ when stored at 4 and $10^{\circ} \mathrm{C}$, respectively (Leggett et al., 2012). The use of $600 \mathrm{MPa}$ of pressure may be essential for inhibiting the growth of these microorganisms, as a previous study reported the recovery and growth of psychrotrophic bacteria, molds, and yeast in cheeses stored at 4 and $8^{\circ} \mathrm{C}$ after HPP treatment at $400 \mathrm{MPa}$ (Evert-Arriagada et al., 2012).

Cost Analysis. In commercial operations, food processors prefer using the shortest hold times possible to maximize production and preserve food quality. In this study, HPP conducted at $600 \mathrm{MPa}$ for QF at an initial temperature of $20^{\circ} \mathrm{C}$, for hold times ranging from 3 to 20 min, was found to reduce L. monocytogenes by up to $7 \log _{10} \mathrm{cfu} / \mathrm{g}$, with repair and then growth of injured cells occurring from 7 to $28 \mathrm{~d}$ after treatment. The same treatment conditions (HPP with either a 3 - or 10-min hold times) were effective in preventing growth of psychrotrophic bacteria, yeasts, and molds for QF stored at either 4 or $10^{\circ} \mathrm{C}$ for up to $84 \mathrm{~d}$ (Figure 4), making it an effective treatment for extending the shelf life and quality of this cheese.

To estimate the costs of HPP for commercial operations, it was assumed that for a plant processing approximately $18,180 \mathrm{~kg} / \mathrm{d}$ of packaged $\mathrm{QF}$, it could be processed at the plant or shipped to a contract facility using a system such as the Avure QFP 350L-600 (Avure Technologies Inc.), which has a high throughput rate. The costs of HPP depend on the pressure and hold time, with a lower hold time favoring increased production rate. For the commercial system above with an assumed 4.1-min loading and unloading time and a 3-min hold time, 7.71 cycles $/ \mathrm{h}$ would be possible when processing $1,905 \mathrm{~kg} / \mathrm{h}$. With a 10 -min hold time and the same time for loading and unloading, only 3.83 pressurizing cycles/h would be possible with a throughput of $959 \mathrm{~kg} / \mathrm{h}$.

The detailed costs for the commercial HPP system are shown in Table 2. Only the costs of the HPP treatment are given and do not include the costs per kilogram of making or packaging the cheese. Regardless of the cycle time, the capital costs for the HPP system are $\$ 2,200,000$ and an additional $\$ 2,200,000$ is assumed for installation, required infrastructure, the building, and auxiliary equipment, for a total capital cost of $\$ 4,400,000$. Annual depreciation is $\$ 440,000$. To calculate the operating costs, production of $5,500 \mathrm{~h} / \mathrm{yr}$ are assumed, with annual production of $10,476,760 \mathrm{~kg} /$ yr for HPP applied for $3 \mathrm{~min}$ and 5,275,532 kg/yr for HPP applied for $10 \mathrm{~min}$.

High-hydrostatic-pressure processing requires 2 operators/shift at $\$ 40.00 / \mathrm{h}$, bringing annual labor charges to $\$ 440,000$. Utility charges include costs of $\$ 4.52 / \mathrm{h}$ for chilled water at $16^{\circ} \mathrm{C}$ and a flow rate of $83.5 \mathrm{~kg} / \mathrm{min}$, with unit costs of $\$ 0.90 / 1,000 \mathrm{~kg}$. Electric power was available at $50 \%$ of peak power (370 kVA peak), or an average $185 \mathrm{~kW}$ at a unit cost of $\$ 0.07 / \mathrm{kWh}$, resulting in costs of $\$ 12.95 / \mathrm{h}$. Annual utility costs are $\$ 96,066$ / yr. Maintenance and part replacement costs were assumed as $8 \%$ of the total capital costs. Administrative costs were assumed as $2 \%$ of capital costs at $\$ 88,000$. The total annual costs for 3 or 10 min of pressurization at $600 \mathrm{MPa}$ were $\$ 1,416,066$. Unit costs per kilogram for pressurizing packages of $\mathrm{QF}$ at $600 \mathrm{MPa}$ for $3 \mathrm{~min}$ are $\$ 0.13 / \mathrm{kg}$ and for $10 \mathrm{~min}$ are $\$ 0.26 / \mathrm{kg}$. This is within the range reported in Rastogi et al. (2007) of $\$ 0.05$ to $\$ 0.50 / \mathrm{kg}$, with lower costs typically associated with thermal processing of foods.

\section{CONCLUSIONS}

High-hydrostatic-pressure processing of $\mathrm{QF}$ at $20^{\circ} \mathrm{C}$, a maximum pressure of $600 \mathrm{MPa}$, and hold time of 20 min was effective for the immediate elimination of $L$. monocytogenes inoculated in the curds or on the surface of QF slices. However, growth of the pathogen resumed after a lag time, which differed depending on whether L. monocytogenes was inoculated in $(7 \mathrm{~d})$ or on the QF slices $(28$ d). High-hydrostatic-pressure processing in conjunction with antimicrobials may help limit the growth of L. monocytogenes during $4^{\circ} \mathrm{C}$ storage. Adjustments in $\mathrm{pH}$, salt content, or water activity of QF may also help limit growth. However, applying the recommendations of Bolton and Frank (1999) for QF formulations that would have a $<5 \%$ probability of $L$. monocytogenes growth would require a salt content ranging from 5 to $11 \%$. High salt content would undoubtedly affect the properties and flavor of the cheese (Leggett 
Table 2. Cost analysis for commercial application of high-hydrostatic-pressure processing (HPP) treatment at $600 \mathrm{MPa}$ on packaged Queso Fresco for 3- or 10-min hold times

\begin{tabular}{|c|c|c|}
\hline \multirow[b]{2}{*}{ Item } & \multicolumn{2}{|c|}{ HPP hold time } \\
\hline & $3 \min$ & $10 \mathrm{~min}$ \\
\hline System capacity (kg/cycle) & 250.5 & 250.5 \\
\hline Cycle time load/unload ( $\mathrm{min}$ ) & 4.1 & 4.1 \\
\hline System percentage utilization & 0.9 & 0.9 \\
\hline Cycles/h & 7.61 & 3.83 \\
\hline Throughput (kg/h) & $1,904.9$ & 959.2 \\
\hline Annual production $(\mathrm{kg} / \mathrm{yr})$ & $10,476,760$ & $5,275,532$ \\
\hline \multicolumn{3}{|l|}{ Capital costs $(\$)$} \\
\hline Avure $350 \mathrm{~L}-600$ system $^{1}$ & $2,200,000$ & $2,200,000$ \\
\hline Installation, infrastructure, and other equipment at $100 \%$ & $2,200,000$ & $2,200,000$ \\
\hline Total capital costs & $4,400,000$ & $4,400,000$ \\
\hline Plant operators/shift (no.) & 2 & 2 \\
\hline \multicolumn{3}{|l|}{ Plant labor costs $(\$)$} \\
\hline Hourly labor charges including overhead & 40.00 & 40.00 \\
\hline Annual labor charges & 440,000 & 440,000 \\
\hline Annual utility charges $(\$)$ & 96,066 & 96,066 \\
\hline \multicolumn{3}{|l|}{ Facility charges $(\$)$} \\
\hline Maintenance & 352,000 & 352,000 \\
\hline Administrative costs & 88,000 & 88,000 \\
\hline Annual facility charges & 440,000 & 440,000 \\
\hline Plant economic life (yr) & 10 & 10 \\
\hline Annual depreciation $(\$)$ & 440,000 & 440,000 \\
\hline Total annual costs $(\$)$ & $1,416,066$ & $1,416,000$ \\
\hline Unit cost $/ \mathrm{kg}$ treated $(\$ / \mathrm{kg})$ & 0.135 & 0.268 \\
\hline
\end{tabular}

${ }^{1}$ Avure Technologies Inc. (Columbus, OH).

et al., 2012). Higher HPP pressures may be effective in eliminating L. monocytogenes, but would likely be cost prohibitive. Even though HPP did not eliminate L. monocytogenes under the conditions of this study, it was effective in eliminating the various microorganisms that can limit the shelf life of QF. This suggests that, at the conditions of this study (600 MPa, initial QF temperature of $20^{\circ} \mathrm{C}$, and either a 3- or 10-min hold time), HPP is a promising postpackaging process that targets spoilage microorganisms throughout the cheese and not just at the surface. This would be an advantage over the use of antimicrobials, which would have to be applied throughout the cheese curd and possibly would alter the flavor of the cheese.

\section{ACKNOWLEDGMENTS}

The authors thank Douglas Soroka for assistance with the scanning electron microscopy studies, Sudarsan Mukhopadhyay for assistance, Andrew McAloon for cost studies, Winnie Yee (all from the US Department of Agriculture, Agricultural Research Service, Eastern Regional Research Center, Wyndmoor, PA) for assistance with the figures, and Nana Farkye (Dairy Products Technology Center, California Polytechnic State University, San Luis Obispo) for advice on the cheese-making procedure. This research was funded in part by Dairy Management Inc. and administered by the Dairy Research Institute (Rosemont, IL) through Agreement No. 58-1935-9-908.

\section{REFERENCES}

Al-Holy, M. A., A. Al-Nabulsi, T. M. Osaili, M. M. Ayyash, and R. R. Shaker. 2012. Inactivation of Listeria innocua in brined white cheese by a combination of nisin and heat. Food Contr. 23:48-53.

Ardia, A., D. Knorr, and V. Heinz. 2004. Adiabatic heat modelling for pressure build-up during high-pressure treatment in liquid-food processing. Food Bioprod. Proc. 82:89-95.

Arroyo, G., P. D. Sanz, and G. Préstamo. 1999. Response to highpressure, low-temperature treatment in vegetables: Determination of survival rates of microbial populations using flow cytometry and detection of peroxidase activity using confocal microscopy. J. Appl. Microbiol. 86:544-556.

Bolton, L. F., and J. F. Frank. 1999. Growth-no growth interface for Listeria monocytogenes in Mexican-style cheeses based on salt, $\mathrm{pH}$ and moisture content. J. Food Prot. 62:601-609.

Calzada, J., A. del Olmo, A. Picón, P. Gaya, and M. Nuñez. 2013. Reducing biogenic-amine-producing bacteria, decarboxylase activity, and biogenic amines in raw milk cheese by high-pressure treatments. Appl. Environ. Microbiol. 79:1277-1283.

Capellas, M., M. Mor-Mur, R. Gervilla, J. Yuste, and B. Guamis, 2000. Effect of high pressure combined with mild heat or nisin on inoculated bacteria and mesophiles of goat's milk fresh cheese. Food Microbiol. 17:633-641.

Chawla, R., G. R. Patil, and A. K. Singh. 2011. High hydrostatic pressure technology in dairy processing: A review. J. Food Sci. Technol. 48:260-268.

Cheftel, J. C. 1995. Review: High-pressure, microbial inactivation and food preservation. Food Sci. Technol. Int. 1:75-90.

Chen, H., and D. G. Hoover. 2003. Modeling the combined effect of high hydrostatic pressure and mild heat on the inactivation kinetics of Listeria monocytogenes Scott A in whole milk. Innov. Food Sci. Emerg. Technol. 4:25-34. 
Considine, K. M., A. L. Kelly, G. F. Fitzgerald, C. Hill, and R. D. Sleator. 2008. High-pressure processing-Effects on microbial food safety and food quality. FEMS Microbiol. Lett. 281:1-9.

Cottrell, M. T., and D. L. Kirchman. 2000. Community composition of marine bacterioplankton determined by $16 \mathrm{~S}$ rRNA gene clone libraries and fluorescence in situ hybridization. Appl. Environ. Microbiol. 66:5116-5122.

Daryaei, H., M. J. Coventry, C. Versteeg, and F. Sherkat. 2006. Effects of high-pressure treatment on shelf life and quality of fresh lactic curd cheese. Aust. J. Dairy Technol. 61:186-188.

Denys, S., A. M. Van Loey, and M. E. Hendrickx. 2000. A modeling approach for evaluating process uniformity during batch high hydrostatic pressure processing: Combination of a numerical heat transfer model and enzyme inactivation kinetics. Innov. Food Sci. Emerg. Technol. 1:5-19.

Evert-Arriagada, K., M. M. Hernández-Herrero, B. Juan, B. Guamis, and A. J. Trujillo. 2012. Effect of high pressure on fresh cheese shelf-life. J. Food Eng. 110:248-253.

Fonberg-Broczek, M., B. Windyga, J. Szczawiński, M. Szczawińska, D. Pietrzak, and G. Prestamo. 2005. High pressure processing for food safety. Acta Biochim. Pol. 52:721-724.

Foulquié Moreno, M. R., P. Sarantinopoulos, E. Tsakalidou, and L. De Vuyst. 2006. The role and application of enterococci in food and health. Int. J. Food Microbiol. 106:1-24.

Gurtler, J. B., R. B. Rivera, H. Q. Zhang, and D. J. Geveke. 2010. Selection of surrogate bacteria in place of E. coli 0157:H7 and Salmonella Typhimurium for pulsed electric field treatment of orange juice. Int. J. Food Microbiol. 139:1-8.

Harvey, A. H., A. P. Peskin, and S. A. Klein. 2004. NIST/ASME Steam Properties. Version 2.21. US Department of Commerce, Technology Administration, National Institute of Standards and Technology, Standard Reference Data Program. National Institute of Standards and Technology, Gaithersburg, MD.

Hayman, M. M., R. C. Anantheswaran, and S. J. Knabel. 2007. The effect of growth temperature and growth phase on the inactivation of Listeria monocytogenes in whole milk subject to high pressure processing. Int. J. Food Microbiol. 115:220-226.

Hendrickx, M., L. Ludikhuyze, I. Van den Broeck, and C. Weemaes. 1998. Effects of high pressure on enzymes related to food quality. Trends Food Sci. Technol. 9:197-203.

Hnosko, J., M. F. San Martin-Gonzalez, and S. Clark. 2012. High pressure processing inactivated Listeria innocua yet compromises Queso Fresco crumbling properties. J. Dairy Sci. 95:4851-4862.

Huppertz, T., P. F. Fox, K. G. de Kruif, and A. L. Kelly. 2006. High pressure-induced changes in bovine milk proteins: A review. Biochim. Biophys. Acta 1764:593-598.

Ivy, R. A., M. L. Ranieri, N. H. Martin, H. C. den Bakker, B. M. Xavier, M. Wiedmann, and K. J. Boor. 2012. Identification and characterization of psychrotolerant sporeformers associated with fluid milk production and processing. Appl. Environ. Microbiol. 78:1853-1864.

Kang, D.-H., and D. Y. C. Fung. 1999. Thin agar layer method for recovery of heat-injured Listeria monocytogenes. J. Food Prot. 62:1346-1349.

Knoerzer, K., and C. Versteeg. 2009. A CFD model for simulating high pressure thermal (HPT) processing - Impact of material properties and processing conditions on prediction accuracy. Pages 1-5 in Proc. 7th Int. Conference on CFD in the Minerals and Process Industries. CSIRO, Melbourne, Australia.

Knorr, D., V. Heinz, and R. Buckow. 2006. High pressure application for food biopolymers. Biochim. Biophys. Acta 1764:619-631.

Leggett, L. N., P. M. Tomasula, D. L. Van Hekken, A. C. S. PortoFett, B. Shoyer, J. A. Renye, J. B. Luchansky, and N. Farkye. 2012. Effect of storage at 4 and $10 \mathrm{C}$ on the growth of Listeria monocytogenes in and on Queso Fresco. J. Food Saf. 32:236-245.

Lin, C.-M., L. Zhang, M. P. Doyle, and B. Swaminathan. 2006. Comparison of media and sampling locations for isolation of Listeria monocytogenes in Queso Fresco cheese. J. Food Prot. 69:21512156.

López-Pedemonte, T., A. Roig-Sagués, S. De Lamo, M. HernándezHerrero, and B. Guamis. 2007. Reduction of counts of Listeria monocytogenes in cheese by means of high hydrostatic pressure. Food Microbiol. 24:59-66.

López-Pedemonte, T. J., A. X. Roig-Sagués, A. J. Trujillo, M. Capellas, and B. Guamis. 2003. Inactivation of spores of Bacillus cereus in cheese by high hydrostatic pressure with the addition of nisin or lysozyme. J. Dairy Sci. 86:3075-3081.

Martínez-Rodríguez, Y., C. Acosta-Muñiz, G. I. Olivas, J. GuerreroBeltrán, D. Rodrigo-Aliaga, and D. R. Sepúlveda. 2012. High hydrostatic pressure processing of cheese. Comp. Rev. Food Sci. Food Saf. 11:399-415.

O'Reilly, C. E., P. M. O'Connor, A. L. Kelly, T. P. Beresford, and P. M. Murphy. 2000. Use of hydrostatic pressure for inactivation of microbial contaminants in cheese. Appl. Environ. Microbiol. 66:4890-4896.

Ogier, J.-C., V. Lafarge, V. Girard, A. Rault, V. Maladen, A. Gruss, J.-Y. Leveau, and A. Delacroix-Buchet. 2004. Molecular fingerprinting of dairy microbial ecosystems by use of temporal temperature and denaturing gradient gel electrophoresis. Appl. Environ. Microbiol. 70:5628-5643.

Patterson, M. F. 2005. Microbiology of pressure-treated foods. J. Appl. Microbiol. 98:1400-1409.

Rasanayagam, V., V. M. Balasubramaniam, E. Ting, C. E. Sizer, C. Bush, and C. Anderson. 2003. Compression heating of selected fatty food materials during high-pressure processing. J. Food Sci. 68:254-259.

Rastogi, N. K., K. S. M. S. Raghavarao, V. M. Balasubramaniam, K. Niranjan, and D. Knorr. 2007. Opportunities and challenges in high pressure processing of foods. Crit. Rev. Food Sci. Nutr. 47:69-112.

Renye, J. A., Jr., G. A. Somkuti, B. Vallejo-Cordoba, D. L. Van Hekken, and A. F. Gonzalez-Cordova. 2008. Characterization of the microflora isolated from Queso Fresco made from raw and pasteurized milk. J. Food Saf. 28:59-75.

Ritz, M., J. L. Tholozan, M. Federighi, and M. F. Pilet. 2001. Morphological and physiological characterization of Listeria monocytogenes subjected to high hydrostatic pressure. Appl. Environ. Microbiol. 67:2240-2247.

Sandra, S., M. A. Stanford, and L. Meunier Goddik. 2004. The use of high-pressure processing in the production of Queso Fresco cheese. J. Food Sci. 69:FEP153-FEP158.

Simonin, H., F. Duranton, and M. de Lamballerie. 2012. New insight into the high-pressure processing of meat and meat products. Comp. Rev. Food Sci. Food Saf. 11:285-306.

Smelt, J. P. P. M. 1998. Recent advances in the microbiology of high pressure processing. Trends Food Sci. Technol. 9:152-158.

Soni, K. A., M. Desai, A. Oladunjoye, F. Skrobot, and R. Nannapaneni. 2012. Reduction of Listeria monocytogenes in Queso Fresco cheese by a combination of listericidal and listeriostatic GRAS antimicrobials. Int. J. Food Microbiol. 155:82-88.

Soni, K. A., R. Nannapaneni, M. W. Schilling, and V. Jackson. 2010. Bactericidal activity of lauric arginate in milk and Queso Fresco cheese against Listeria monocytogenes cold growth. J. Dairy Sci. 93:4518-4525.

Szczawiński, J., B. Stańczak, and J. Peconek. 2003. Survival of Enterococcus hirae in ripened cheese subjected to ultra high pressure. Pol. J. Vet. Sci. 6:267-269.

Trujillo, A. J., M. Capellas, J. Saldo, R. Gervilla, and B. Guamis. 2002. Applications of high-hydrostatic pressure on milk and dairy products: A review. Innov. Food Sci. Emerg. Technol. 3:295-307.

Van Hekken, D. L., M. H. Tunick, N. Y. Farkye, and P. M. Tomasula 2013. Impact of hydrostatic high-pressure processing on the chemical, functional, and rheological properties of starter-free Queso Fresco. J. Dairy Sci. 96:6147-6160.

Van Hekken, D. L., M. H. Tunick, L. N. Leggett, and P. M. Tomasula. 2012. Impact of curd milling on the quality traits of starter-free pasteurized Queso Fresco. J. Dairy Sci. 95:5527-5535.

Zhang, H., and G. S. Mittal. 2008. Effects of high-pressure processing (HPP) on bacterial spores. Food Rev. Int. 24:330-351. 